Article

\title{
Predicting Growing Stock Volume of Eucalyptus Plantations Using 3-D Point Clouds Derived from UAV Imagery and ALS Data
}

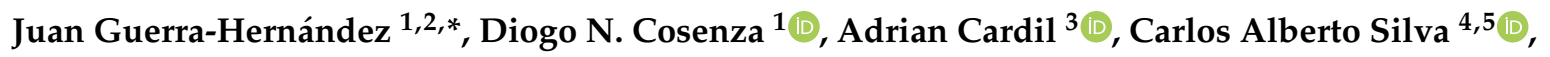 \\ Brigite Botequim $^{1}{ }^{(\mathbb{D}}$, Paula Soares ${ }^{1}\left(\mathbb{D}\right.$, Margarida Silva ${ }^{6}$, Eduardo González-Ferreiro ${ }^{7} \mathbb{C}$ and \\ Ramón A. Díaz-Varela ${ }^{8}$ (D) \\ 1 Forest Research Centre, School of Agriculture, University of Lisbon, Instituto Superior de Agronomia (ISA), \\ Tapada da Ajuda, 1349-017 Lisboa, Portugal; dncosenza@gmail.com (D.N.C.); \\ bbotequim@isa.ulisboa.pt (B.B.); paulasoares@isa.ulisboa.pt (P.S.) \\ 2 3edata. Centro de iniciativas empresariais. Fundación CEL. O Palomar s/n, 27004 Lugo, Spain \\ 3 Tecnosylva. Parque Tecnológico de León. 24009 León, Spain; adriancardil@gmail.com \\ 4 Biosciences Laboratory, NASA Goddard Space Flight Center, Greenbelt, MD 20707, USA; \\ carlos_engflorestal@outlook.com \\ 5 Department of Geographical Sciences, University of Maryland, College Park, Maryland, MD 20740, USA \\ 6 RAIZ (Forest and Paper Research Institute), The Navigator Company, Rua José Estevão, 3800-783 Eixo, \\ Portugal; margarida.silva@thenavigatorcompany.com \\ 7 Departamento de Tecnología Minera, Topografía y de Estructuras, Grupo de Investigación en Geomática e \\ Ingeniería Cartográfica GI-202-GEOINCA, Escuela Superior y Técnica de Ingenieros de Minas, Universidad \\ de León, Av. de Astorga s/n, Campus de Ponferrada, 24401 Ponferrada, Spain; egonf@unileon.es \\ 8 Biodiversity and Applied Botany Unit (GI BIOAPLIC 1809), Department of Botany, University of Santiago de \\ Compostela, Escuela Politécnica Superior, R/Benigno Ledo, Campus Universitario, 27002 Lugo, Spain; \\ ramon.diaz@usc.es \\ * Correspondence: juanguerra@isa.ulisboa.pt or juan.guerra@3edata.es; Tel.: +351-21-365-3356
}

Received: 9 September 2019; Accepted: 8 October 2019; Published: 15 October 2019

check for updates

\begin{abstract}
Estimating forest inventory variables is important in monitoring forest resources and mitigating climate change. In this respect, forest managers require flexible, non-destructive methods for estimating volume and biomass. High-resolution and low-cost remote sensing data are increasingly available to measure three-dimensional (3D) canopy structure and to model forest structural attributes. The main objective of this study was to evaluate and compare the individual tree volume estimates derived from high-density point clouds obtained from airborne laser scanning (ALS) and digital aerial photogrammetry (DAP) in Eucalyptus spp. plantations. Object-based image analysis (OBIA) techniques were applied for individual tree crown (ITC) delineation. The ITC algorithm applied correctly detected and delineated 199 trees from ALS-derived data, while 192 trees were correctly identified using DAP-based point clouds acquired from Unmanned Aerial Vehicles (UAV), representing accuracy levels of respectively $62 \%$ and $60 \%$. Addressing volume modelling, non-linear regression fit based on individual tree height and individual crown area derived from the ITC provided the following results: Model Efficiency (Mef) $=0.43$ and 0.46, Root Mean Square Error (RMSE) $=0.030 \mathrm{~m}^{3}$ and $0.026 \mathrm{~m}^{3}, \mathrm{rRMSE}=20.31 \%$ and $19.97 \%$, and an approximately unbiased results $\left(0.025 \mathrm{~m}^{3}\right.$ and $0.0004 \mathrm{~m}^{3}$ ) using DAP and ALS-based estimations, respectively. No significant difference was found between the observed value (field data) and volume estimation from ALS and DAP ( $p$-value from $t$-test statistic $=0.99$ and 0.98 , respectively). The proposed approaches could also be used to estimate basal area or biomass stocks in Eucalyptus spp. plantations.
\end{abstract}

Keywords: unmanned aerial vehicles (UAV); forest inventory; volume; canopy height model (CHM); object based image analysis (OBIA); structure from motion (SfM) 


\section{Introduction}

Sustainable forest management demands accurate information that can be obtained efficiently and rapidly [1] in order to describe forest structure and quantify forest resources [2]. However, although accurate, traditional forest inventory is resource- and time-consuming, indicating the need for either alternative or complementary methods that may overcome the drawbacks of field data acquisition [3]. In addition, although field-measured data are commonly assumed to be ground truth values for remote sensing estimations, the associated errors tend to be large [3-6].

A number of alternatives to traditional field-based measurement of morphological parameters for characterizing three-dimensional (3D) structure of trees and canopies have emerged [4,7]. Airborne Laser Scanning (ALS), Digital Aerial Photogrammetry (DAP) and Terrestrial Laser Scanning (TLS) have become widely established as forest mapping and monitoring methods [8-11]. In the last two decades, DAP, ALS (e.g., [12-14]) or a combination of these methods (e.g., [15-17]) have been increasingly used to support forest inventories at different scales.

ALS has been the primary source of 3D data on forest vertical structure since the 1990s [18,19]. There has been an abundance of research demonstrating the utility of ALS for predicting forest biophysical variables to support forest inventories at individual tree- and stand-level $[20,21]$. Since the late 2000s DAP has provided a promising alternative, as the accuracy of stand-based estimates has been found to be similar to that achieved through ALS, at much lower cost $[17,22,23]$.

Baltsavias [12] provided a comprehensive comparison of DAP and ALS data, highlighting the advantages and disadvantages of both technologies with regards to acquisition, accuracy, maturity and costs. Although ALS data have many advantages (e.g., direct measurement of height, higher penetration through the vegetation), DAP still represents an essential source of data for the forest inventory analyses. In fact, photogrammetric software has developed rapidly in the past 15-20 years. Since the first studies [24], advances in computer vision, image matching algorithms and computing power have promoted the use of aerial images for generating high-resolution 3D data by image matching [25]. Many photogrammetric software packages (proprietary and open-source) have been developed, offering unparalleled opportunities to produce 3D data from 2D image collections with high overlap.

Recent advances in sensors and in image processing -particularly Structure from Motion (SfM) technology- have also enabled the extraction of dense point clouds obtained by DAP [16,24,26-29]. In this sense, DAP derived from SfM is an emerging source of 3D data, reaching quality standards close to those provided by ALS [25,30]. works by [26,31-33] pointed out the potential of DAP for forest applications. During the past five years in particular, there has been an increasing interest in the use of DAP to generate 3D data analogous to ALS data, in order to support forest inventories [17,22,25,34-39]. This interest can be attributed to the need to optimize costs while improving the temporal resolution.

Unmanned Aerial Vehicles (UAVs), also known as drones or Unmanned Aerial Systems (UAS), have emerged as a cost-effective alternative to conventional methods based on manned fixed-wing aircraft or helicopters for DAP imagery and ALS data collection [40-43]. Since the first studies in which UAV-derived data was used for forest inventory purposes [44,45], UAV-based forestry applications of both ALS and DAP have increased substantially [40,46-52]. Indeed, ALS and Red-Green-Blue (RGB) sensors mounted on UAV platforms are becoming cost-effective tools for monitoring forest structure because of their high spatial and temporal resolution, achieved by the low flight height, operational flexibility and relatively low cost of the flight surveys, which meet most of forest managers requirements [53]. In particular, light UAVs equipped with inexpensive consumer grade cameras have recently appeared as a feasible option for monitoring $3 \mathrm{D}$ forest structure [54]. In addition, multi-temporal UAV-acquired data can also be used for rapid, accurate and cost-effective tree growth assessment, providing up-to-date information to support decision-making in forest management [48,54-58].

Two main strategies have been adopted for DAP and ALS-based analysis in forestry inventories: (i) the Area-Based Approach (ABA), a distribution-based technique which typically provides data at stand level, and (ii) the individual tree crown (ITC) delineation, in which individual tree crowns, 
heights and positions are the basic units of assessment. ABA has been used with ALS and DAP to estimate forest attributes over a wide range of forest types including Temperate (e.g., [59]), Boreal (e.g., [13,14,17,34,60]), Atlantic (e.g., [61,62]), Tropical (e.g., [37]), Alpine (e.g., [63,64]), Mediterranean forests (e.g., [65-69]) and plantations [70]. At the stand level, results from recent research on small- to medium-sized boreal and tropical forests have demonstrated the potential use of UAV-based DAP data for estimating forest biomass $[53,71]$. On the other hand, ITC has also been applied to DAP point clouds [72] and to ALS clouds [73,74]. ITC presents several advantages over ABA for estimation of above-ground biomass because it can be used to derive biomass when an allometric model is available at individual tree level [75]. At the same time, it is particularly well suited for precision forestry, which usually requires information about individual trees.

Finally, ALS and SfM approaches to tree height estimation tend to underestimate tree height [73,74,76,77]. Recent studies [77] have presented a model that explains the observed bias using probability theory, developing methods for correcting several ALS metrics used for ABA prediction of stand structure. However, few studies have evaluated the influence of this bias at individual-tree level. In this respect, further research is needed in order to analyze the influence of this bias in the individual-tree biomass and volume models for both technologies.

The objectives of this study were as follows: (i) to investigate the combined use of ALS- and SfM-derived individual-tree measurements (height and crown area) with non-linear regression models to estimate individual tree diameter and volume; and (ii) to compare the estimation of ALS- and SfM-derived individual-tree volume models to estimate growing stock volume in relation to field data.

\section{Materials and Methods}

\subsection{Study Area}

The study area is located in the municipality of Valongo $\left(41.213^{\circ} \mathrm{N},-8.496^{\circ} \mathrm{W}\right)$ in the district of Porto, Portugal (Figure 1). The site consists of a seven year old plantation of Eucalyptus spp. clonal material (G74), covering an area of 26 ha. Tree spacing was $3.70 \times 2.5 \mathrm{~m}$, yielding a density of one tree per $9.25 \mathrm{~m}^{-2}$. The elevation ranges from 163 to $294 \mathrm{~m}$ above the WGS84 reference ellipsoid. The terrain is topographically complex, with steep slopes (mean slope $=24.2 \%$ ), and of elevation up to $131 \mathrm{~m}$. The mean annual rainfall is $1568 \mathrm{~mm}$, and $42.1 \%$ of the precipitation occurs between November and January. The mean annual temperature is $14.2^{\circ} \mathrm{C}$, ranging from $8.6^{\circ} \mathrm{C}$ in the coldest months (December to February) to $20.1^{\circ} \mathrm{C}$ in the warmest months (July to September). The study site is characterized by evenly planted trees of superior genetic material with a low mortality rate.
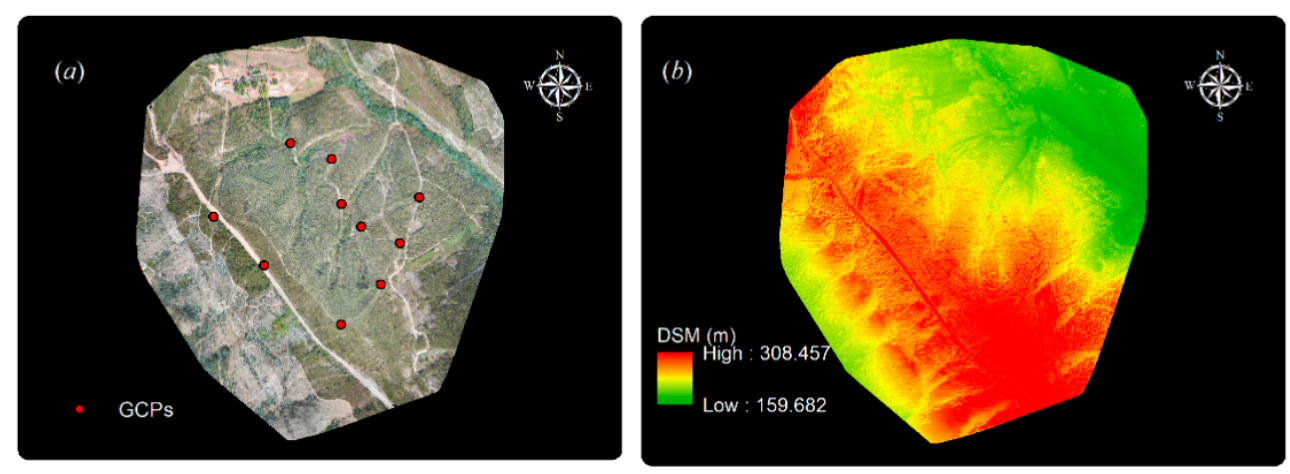

Figure 1. (a) UAV-derived RGB-orthomosaic image of the study area and 10 ground control points (GCPs) (red dots) (b) UAV-derived Digital Surface Model (DSM) generated using Pix $4 \mathrm{~d}^{\circledR}$ software.

\subsection{Field Measurements and Field Volume Estimation}

The field data were collected in December 2016 (to correspond to the date of acquisition of ALS data) from 6 square plots, each of approximately $400 \mathrm{~m}^{2}$ (Table 1). A total of 323 reference trees were 
measured and located in 6 square plots $\left(400 \mathrm{~m}^{2}\right)$. The height of each tree $(h, \mathrm{~m})$ within the plots was measured with a Haglof Vertex IV hypsometer equipped with a T3 transponder. The diameter at breast height $(1.30 \mathrm{~m}$ above the ground $-d, \mathrm{~cm})$ was measured with a steel diameter measuring tape. Field plots were remeasured using the same methods in September 2017 (matching with UAV-based DAP acquisition).

Table 1. Statistical description of the field data within six field plots for a total of 323 reference trees

\begin{tabular}{ccccccc}
\hline Plot & \multicolumn{2}{c}{$\boldsymbol{d}$} & \multicolumn{2}{c}{$\boldsymbol{c}$} & \multicolumn{2}{c}{$\hat{\boldsymbol{v}}$} \\
\hline & \multicolumn{2}{c}{ Mean } & \multicolumn{2}{c}{ Mean } & \multicolumn{2}{c}{ Mean } \\
\hline & Dec 2016 & Sep 2017 & Dec 2016 & Sep 2017 & Dec 2016 & Sep 2017 \\
\cline { 2 - 7 } P1 & 13.2 & 13.4 & 19.4 & 20.9 & 0.13 & 0.14 \\
P2 & 12.9 & 13.3 & 18.8 & 19.9 & 0.12 & 0.15 \\
P3 & 13.4 & 13.8 & 18.6 & 20.0 & 0.13 & 0.15 \\
P4 & 13.8 & 14.1 & 18.8 & 19.8 & 0.13 & 0.15 \\
P5 & 13.7 & 14.0 & 18.3 & 19.7 & 0.13 & 0.15 \\
P6 & 13.8 & 14.2 & 17.6 & 19.1 & 0.13 & 0.14 \\
\hline Min. & 5.3 & 5.4 & 9.9 & 10.3 & 0.01 & 0.01 \\
Mean & 13.5 & 13.8 & 18.6 & 19.9 & 0.13 & 0.14 \\
Max. & 17.3 & 17.8 & 22.8 & 23.5 & 0.24 & 0.26 \\
SD & 1.7 & 1.7 & 1.5 & 1.6 & 0.03 & 0.04 \\
\hline
\end{tabular}

Average (Mean), minimum (Min), maximum (Max) and standard deviation (SD), values of the individual tree diameter $(\mathrm{d}, \mathrm{cm})$, height $(\mathrm{h}, \mathrm{m})$ and field data volume estimation $\left(\hat{v}, \mathrm{~m}^{3}\right)$.

In order to obtain accurate positions of the trees, topographic surveys were conducted to determine the position of the center of each tree within the plots. A Trimble ${ }^{\circledR}$ TSC3 GPS controller with Trimble ${ }^{\circledR}$ R8s Integrate GNSS System Antenna (Trimble, Sunnyvale, CA, USA) (dual-frequency real-time kinematic receiver-RTK) was used to determine the coordinates of a densified geodetic network for the study area by applying real time kinematic (RTK). Based on the network established with GPS, a topographic survey of the plots was conducted using a Trimble ${ }^{\circledR}$ M3 Robotic Total Station (Trimble, Sunnyvale, CA, USA). Observations on the position of each tree within the plot were made during the survey.

Field-derived volumes were estimated using the Equation (1), provided by [78].

$$
\hat{v}=0.2105\left(\frac{d}{100}\right)^{1.8191} h^{1.0703}
$$

where $\hat{v}$ is the estimated volume $\left(\mathrm{m}^{3}\right), d$ is the diameter $(\mathrm{cm})$ at the breast height $(1.30 \mathrm{~m})$ and $h$ is the tree height $(\mathrm{m})$.

\subsection{ALS Acquisition}

The airborne surveys were conducted on 17 December 2016, covering an area of 100 ha. The data were captured with Leica ALS80-HP laser scanner operating at pulse rate of $704 \mathrm{kHz}$, field of view of $6.5^{\circ}$ and scan rate of $73.5 \mathrm{~Hz}$, which was mounted on a Cessna airplane that flew the area at an approximately flight altitude of 2750 m.a.s.l and an average speed of $250 \mathrm{~km} . \mathrm{h}^{-1}$. The overlap between sweeps was 30\%, achieving an average laser pulse density of 43.33 pulses $\mathrm{m}^{-2}$.

\subsection{UAV Data Acquisition and Use}

The airborne surveys were conducted on 6 September 2017. An RGB S.O.D.A. 10.2 (20 MP) camera (senseFly Co, Cheseaux-Lausanne, Switzerland) was mounted, with nadir view, on a fixed-wing UAV (SenseFly eBee) (Figure 2). The camera, which was equipped with a $12.75 \times 8.5 \mathrm{~mm}$ sensor 
and $5472 \times 3648$ pixels detector, was used in manual mode. Exposure settings (ISO 150 and shutter speed of 1/1000 s) were set before each take-off according to the light conditions. This provided $\sim 6 \mathrm{~cm}$ pixel $^{-1}$ resolution for a variable altitude above ground level, which is especially useful in areas of diverse elevation range such as mountainous regions. Atmospheric conditions during the airborne surveys were characterized by calm winds, clear lighting at the flight time (between $11.30 \mathrm{am}$ and $12.15 \mathrm{pm}$ ) to minimize the effect of shadowing. Flight parameters were determined using eMotion V. 3.2.4 flight planning and monitoring software. The flight plan covered the entire study area with longitudinal and lateral overlaps of $85 \%$ in both cases. The flight line spacing was $25 \mathrm{~m}$ (Figure 2). In total, 744 images were used to generate orthomosaics and Digital Surface Models (DSMs) by the SfM image reconstruction process. Two-block flights were required to capture the entire forest study area (the orthomosaic covered an area 103.70 ha with average Ground Sample Distance (GSD) of $5.95 \mathrm{~cm}$ ).

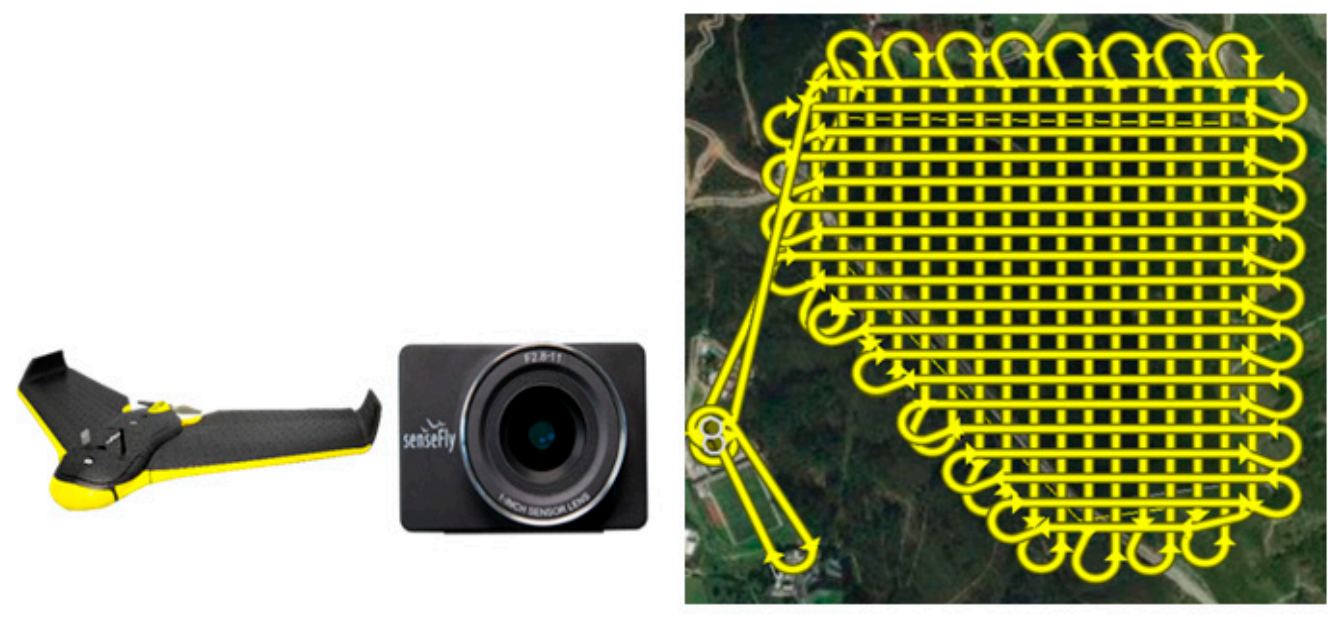

Figure 2. UAV Camera (left) and flight design (right).

\subsection{D Model Generation and Preprocessing Point Clouds}

The absolute orientation of the aerial photos was determined using aerotriangulation techniques implemented in pix4D 3.3.29 (pix $4 \mathrm{D}^{\circledR}$, Ecublens, Switzerland). A set of 10 ground control points (GCPs) measured in the field with topographic methods was used to georeference the SfM mosaics to a projected coordinate system for both datasets. The ground control photogrammetric points (GCPs) were captured with a Trimble TSC3 controller and a Trimble R8s GNSS antenna (RTK precision $8 \mathrm{~mm}+$ $1 \mathrm{ppm}$ Horizontal/15 mm $+0.5 \mathrm{ppm}$ Vertical) mounted on a pole. The GCPs markers comprised a set of $1 \times 1 \mathrm{~m}$ cross-shaped white painted timber planks with some black and white $50 \times 50 \mathrm{~cm}$ painted checkerboards. For reliable accuracy of GPS measurement, all GCPs were located in open areas with no canopy cover. At each point, GPS signals were logged in RTK-global navigation satellite system (GNSS) mode. The recordings were processed with real-time correction data retrieved from the fixed base station in Gaia (Porto) (latitude: $41^{\circ} 06^{\prime} 21.67048^{\prime \prime} \mathrm{N}$, longitude: $8^{\circ} 35^{\prime} 20.73434^{\prime \prime} \mathrm{W}$, and ellipsoidal elevation: $287.63 \mathrm{~m}$ above the WGS84 reference ellipsoid).

Photogrammetric point clouds were computed using SfM techniques, implemented in Pix4D 3.3.29. The matching parameters for point cloud densification were set as follows: multiscale, image scale $=$ $1 / 2$ (half image size) and point density = 'optimal'. The minimum number of matched images was also set to 3. DEM $\mathrm{SfM}_{\mathrm{M}}$ was generated from the ground points by using a natural neighbor interpolation technique implemented in Pix4D (additional details of the algorithms are proprietary and were not disclosed by Pix4D).

The ALS and SfM point clouds preprocessed using FUSION/LDV 3.60 software [79] and LasTools [80]. For more details of point cloud processing see details in [74]. Finally, two CHMs $\left(\mathrm{CHM}_{\mathrm{SfM}}\right.$ and $\left.\mathrm{CHM}_{\mathrm{ALS}}\right)$ were obtained by subtracting the DEMs $\left(\mathrm{DEM}_{\mathrm{ALS}}\right.$ and $\left.\mathrm{DEM} \mathrm{M}_{\mathrm{SfM}}\right)$ from the DSMs $\left(\mathrm{DSM}_{\mathrm{ALS}}\right.$ and DSM $\left.\mathrm{SfM}_{\mathrm{M}}\right)$ in the FUSION LiDAR Toolkit [79]. 


\subsection{ITC Process to Derive ALS- and SfM-Variables}

Individual tree position ( $X$ and $Y$ coordinates), height $\left(h_{S f M}, h_{A L S}\right)$ and crown area $\left(c a_{S f M}, c a_{A L S}\right)$ were retrieved from the respective $\mathrm{CHM}_{\mathrm{SfM}}$ and $\mathrm{CHM}_{\mathrm{ALS}}$ (Figure 2). Resampling of the CHMs to $20 \mathrm{~cm}$ resolution and subsequent smoothing with mean filter $(5 \times 5$ window $)$ in the case of ALS and median filters $(3 \times 3$ window) for SfM were conducted using the FUSION LiDAR Toolkit [79]. Crown delineation followed the procedure detailed in [81]. The process is divided into three main phases: segmentation, classification and iterative watershed segmentation The Chessboard Segmentation algorithm was used to split the image into square image objects. In the second phase, a Classification algorithm was used to classify image objects from the smoothed CHM. Objects with an elevation value of less than $5 \mathrm{~m}$ were classified as gaps. The threshold was established empirically from field observations and by trial-and-error tests. The remaining objects were assigned to the temporary canopy' class. These objects were used to locate tree tops and delineate tree crowns in the following iterative watershed segmentation processes. In the iteration, the Find Local Extrema algorithm was used to classify the image objects of the 'temporary canopy' class, which fulfills a local extreme condition according to image object features within a search domain in their neighborhoods. However, because of the forest stand and tree species characteristics, the initial maximum search domain used in the iterative process (see Figure 3 in [81]) to detect top trees was changed from 5 to 3, and 4 interactions were applied. A search with a variable square window enables detection of apices of trees with a large variety of crown sizes. Objects less than $3 \mathrm{~m}$ away from any detected tree top were retained in the 'temporary canopy' class (candidates for watershed) and any other objects were disregarded. This distance was the maximum observed crown width in the plots, which was considered the limit for crown growing in the next step. Then, the crown delineation results (Figure 3) and tree top positions were exported in ESRI ${ }^{\mathrm{TM}}$ shapefiles as vector polygons and points respectively, for subsequent analysis.
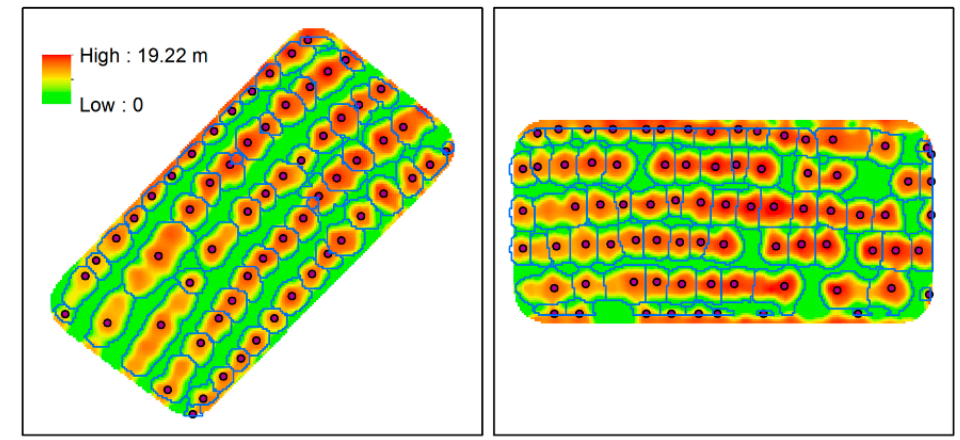

(a)
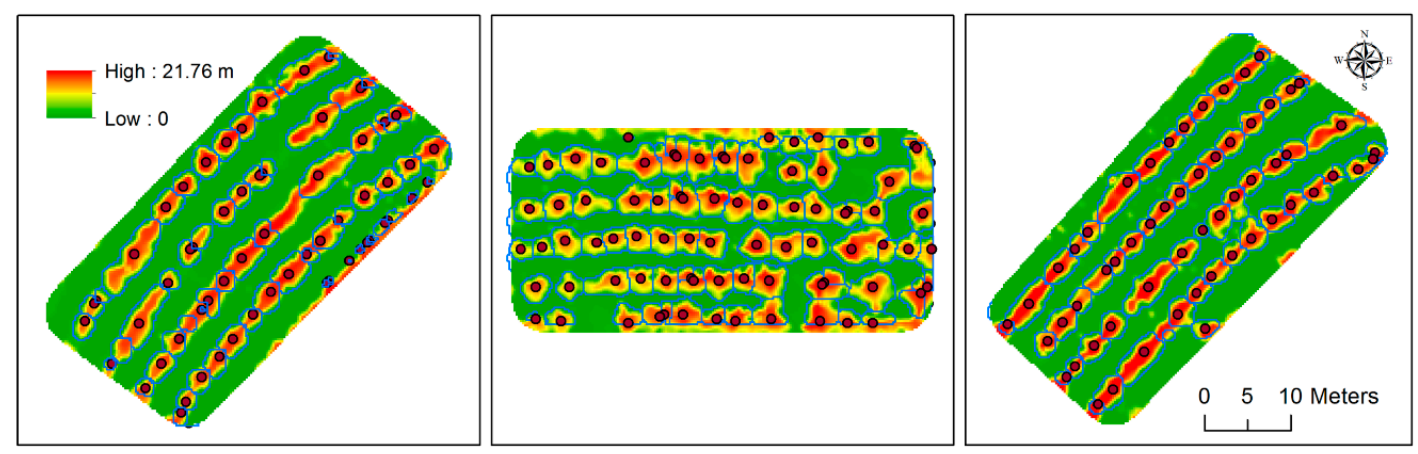

(b)

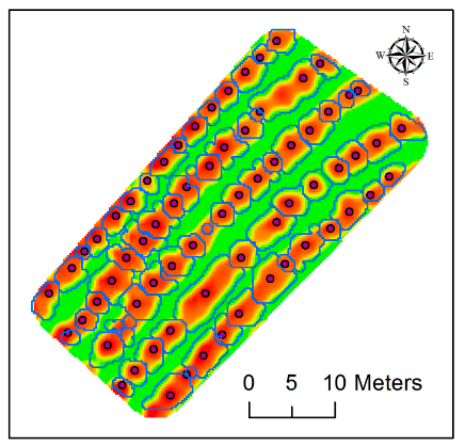

1

Figure 3. Examples of the canopy height models (cool to warm colors representing low to high heights), crown delineation (blue lines), and tree top positions (red dots) within example plots using airborne laser scanning (ALS) (a) and Structure from Motion (SfM) (b). 


\subsection{Individual Tree Volume Estimation}

Volume equation (Equation (1)) requires the measurement of tree diameter or circumference, which is not available from UAV imagery. We therefore tested two approaches for estimating ALS- and SfM-derived individual-tree volumes $\left(v_{S f M}\right.$ and $\left.v_{A L S}\right)$ (Figure 4$)$. In the first approach, the multiplicative (power function) model in Equation (2) was fitted using $d$ (from field data) as the dependent variable and the pairs of explanatory variables $h_{S f M}, c a_{S f M}$ for SfM, or $h_{A L S}, c a_{A L S}$ for ALS. The predicted diameter obtained by each method $\left(d_{S f M}\right.$ and $\left.d_{A L S}\right)$ and their respective height estimates $\left(h_{S f M}\right.$ and $\left.h_{A L S}\right)$ were then included as independent variables in Equation (1) to predict the individual volumes for the subset of 192 trees for ALS and 199 for SfM ( $v_{S f M}$ and $v_{A L S}$, respectively). In the second approach, the multiplicative (power function) model in Equation (3) was also fitted to predict $v_{S f M}$ and $v_{A L S}$ for the 192 and 199 trees respectively, but $v$ was considered a dependent variable (estimated using the field-measured $d$ and $h$ in Equation (1)), and the pairs $h_{S f M}, c a_{S f M}$ (from SfM) or $h_{A L S}, c a_{A L S}$ (from ALS) were considered explanatory variables, without the need to estimate the diameters.

$$
\begin{aligned}
& \hat{d}=h^{\beta_{0}} c a^{\beta_{1}}+\varepsilon \\
& \hat{v}=h^{\beta_{0}} c a^{\beta_{1}}+\varepsilon
\end{aligned}
$$

where $\hat{v}$ is the estimated volume $\left(\mathrm{m}^{3}\right), \hat{d}$ is the estimated tree diameter $(\mathrm{cm}), h$ is the tree height $(\mathrm{m})$, $c a$ is the canopy area $(\mathrm{m})$, generated from ALS or SfM, $\beta_{0}, \beta_{1}$, are the exponential parameters to be estimated by non-linear regression analysis; and $\varepsilon$ is the additive random error. The models were fitted using the Non-linear Least Squares nls function implemented in the BASE package of R software ( $\mathrm{R}$ Core Team, 2018).

Finally, the Model Efficiency (Mef, Equation (4)), the overall root mean square error (RMSE, Equation (5)), the relative root mean square error (rRMSE, Equation (6)) and the Bias (Equation (7)) were computed in order to determine the accuracy of ALS and SfM models for estimating diameter and volume with the second approach. Mef compares predictions directly with observed data using a statistic analogous to $\mathrm{R}^{2}$ [82]. This statistic provides a simple index of performance on a relative scale, where 1 indicates a 'perfect' fit, 0 reveals that the model is no better than a simple average, and negative values indicate a poor model.

$$
\begin{gathered}
\text { Mef }=1-\left(\frac{(n-1) \sum_{i=1}^{n}\left(y_{i}-\hat{y}_{i}\right)^{2}}{(n-p) \sum_{i=1}^{n}\left(y_{i}-\bar{y}\right)^{2}}\right) \\
\text { RMSE }=\sqrt{\frac{\sum_{i=1}^{n}\left(y_{i}-\hat{y}_{i}\right)^{2}}{n}} \\
\text { rRMSE }=\frac{R M S E}{\bar{y}} * 100 \\
\text { Bias }=\frac{\sum_{i=1}^{n}\left(\hat{y}_{i}-y_{i}\right)}{n}
\end{gathered}
$$

where $n$ is the number of trees; $y_{i}$ is the field-measured tree diameter $i ; \bar{y}$ is the the mean observed value for the field-measured diameters; $\hat{y}_{i}$ is the estimated value of diameter derived from the non-linear regression model and $p$ is the number of parameters in the models.

Finally, using the correctly detected and delineated trees, $d$ was compared with $d_{S f M}, d_{A L S}$ and $v$ with $v_{S f M}, v_{A L S}$ in the subsample of 192 trees for SfM and 199 for ALS, respectively. Estimated and observed values were plotted and visually examined. A paired $t$-test was conducted to compare ALSand SfM-predicted variables $\left(d_{S f M}, d_{A L S}, v_{S f M}\right.$, and $\left.v_{A L S}\right)$ to verify the significance of the deviations between the observed and estimated values. However, these deviations were previously checked using 
the Shapiro-Wilk test [83], which indicated that the distributions meet the assumption of normality. The tests were conducted at a 5\%significance level.

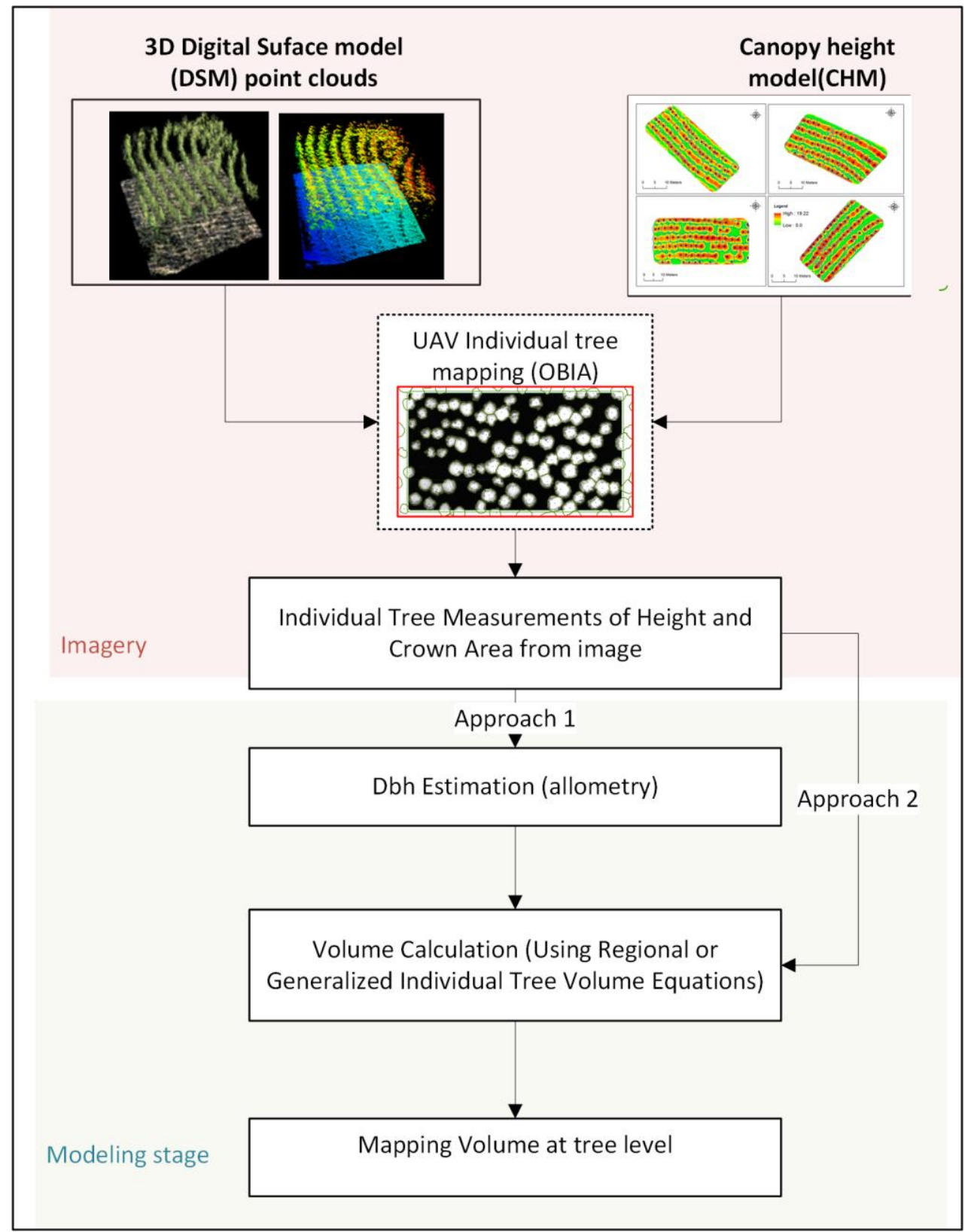

Figure 4. Summary steps of individual tree crown (ITC) to map volume.

\section{Results}

\section{Field, ALS and SfM Volume Estimation}

Table 2 shows the parameter estimates and goodness-of-fit statistics for the models used to predict $d(\mathrm{~cm})$ in the first approach, and $v$ directly estimated by SfM- and ALS-variables in the second approach.

In the first approach, non-linear regression yielded an Mef value of 0.45 for the SfM-estimated diameter and 0.47 for ALS-estimated diameter (RMSE = 1.17 and $1.12 \mathrm{~cm}, \mathrm{rRMSE}$ of $8.49 \%$ and $8.31 \%$, respectively). Although the UAV-based DAP method tends to underestimate tree height relative to field measurements (hypsometers), there was no appreciable bias throughout the observed diameter (Figure 5a,b). The bias values $(0.38$ and $0.35 \mathrm{~cm})$ indicated a slight tendency to overestimate the initial diameter values from field data (Figure $5 \mathrm{a}, \mathrm{b}$ ). On the other hand, although $d$ was not directly measured 
in CHMs derived from UAV and ALS, $h_{S f M}$ and $h_{A L S}$ were, and these variables were significant in the SfM and ALS equations. For $d_{S f M}$ and $d_{A L S}$ modelling, the crown area $\left(c a_{S f M}\right.$ and $\left.c a_{A L S}\right)$ was also statistically significant $(p<0.05$ and $p<0.001$, respectively).

Table 2. Models selected for estimating SfM and ALS derived individual tree diameter and volume.

\begin{tabular}{|c|c|c|c|c|c|c|c|c|c|}
\hline Approach & $\begin{array}{c}\text { Dependent } \\
\text { variable }\end{array}$ & Predictors & $\begin{array}{l}\text { Parameter } \\
\text { estimate }\end{array}$ & $\begin{array}{l}\text { Standard } \\
\text { error }\end{array}$ & $p$-value & Mef & $\begin{array}{l}\text { RMSE } \\
\text { (cm) }\end{array}$ & $\begin{array}{c}\text { rRMSE } \\
(\%)\end{array}$ & $\begin{array}{l}\text { bias } \\
\text { (cm) }\end{array}$ \\
\hline \multirow{6}{*}{1 st } & \multirow{3}{*}{$d_{S f M}$} & Constant & 0.863 & 1.170 & $<0.001$ & \multirow{3}{*}{0.45} & \multirow{3}{*}{1.17} & \multirow{3}{*}{8.49} & \multirow{3}{*}{0.38} \\
\hline & & $h_{S f M}$ & 0.907 & 0.108 & $<0.001$ & & & & \\
\hline & & $c a_{S f M}$ & 0.037 & 0.037 & 0.013 & & & & \\
\hline & \multirow{3}{*}{$d_{A L S}$} & Constant & 0.564 & 0.151 & $<0.001$ & \multirow{3}{*}{0.47} & \multirow{3}{*}{1.12} & \multirow{3}{*}{8.31} & \multirow{3}{*}{0.35} \\
\hline & & $h_{A L S}$ & 1.042 & 0.090 & $<0.001$ & & & & \\
\hline & & $c a_{A L S}$ & 0.062 & 0.015 & $<0.001$ & & & & \\
\hline Approach & $\begin{array}{c}\text { Dependent } \\
\text { variable }\end{array}$ & Predictors & $\begin{array}{l}\text { Parameter } \\
\text { estimate }\end{array}$ & $\begin{array}{l}\text { Standard } \\
\text { error }\end{array}$ & $p$-value & Mef & $\begin{array}{c}\text { RMSE } \\
\left(\mathrm{m}^{3}\right)\end{array}$ & $\begin{array}{c}\text { rRMSE } \\
(\%)\end{array}$ & $\begin{array}{l}\text { bias } \\
\left(\mathrm{m}^{3}\right)\end{array}$ \\
\hline \multirow{6}{*}{ 2nd } & \multirow{3}{*}{$v_{S f M}$} & Constant & 0.004 & 0.002 & 0.082 & \multirow{3}{*}{0.43} & \multirow{3}{*}{0.030} & \multirow{3}{*}{20.31} & \multirow{3}{*}{0.001} \\
\hline & & $h_{S f M}$ & 1.192 & 0.201 & $<0.001$ & & & & \\
\hline & & $c a_{S f M}$ & 0.151 & 0.035 & $<0.001$ & & & & \\
\hline & \multirow{3}{*}{$v_{A L S}$} & Constant & 0.001 & 0.000 & 0.106 & \multirow{3}{*}{0.46} & \multirow{3}{*}{0.026} & \multirow{3}{*}{19.97} & \multirow{3}{*}{0.000} \\
\hline & & $h_{A L S}$ & 1.828 & 0.224 & $<0.001$ & & & & \\
\hline & & $c a_{A L S}$ & 0.024 & 0.037 & $<0.001$ & & & & \\
\hline
\end{tabular}

$h_{S f M}$ and $h_{A L S}$ are the SfM and ALS-derived tree height (m), $c a_{S f M}$ and $c a_{A L S}$ are the SfM and ALS-derived individual crown area $\left(\mathrm{m}^{2}\right)$, Mef is the model efficiency statistic, RMSE is the root mean squared error and rRMSE is the relative root mean square error.
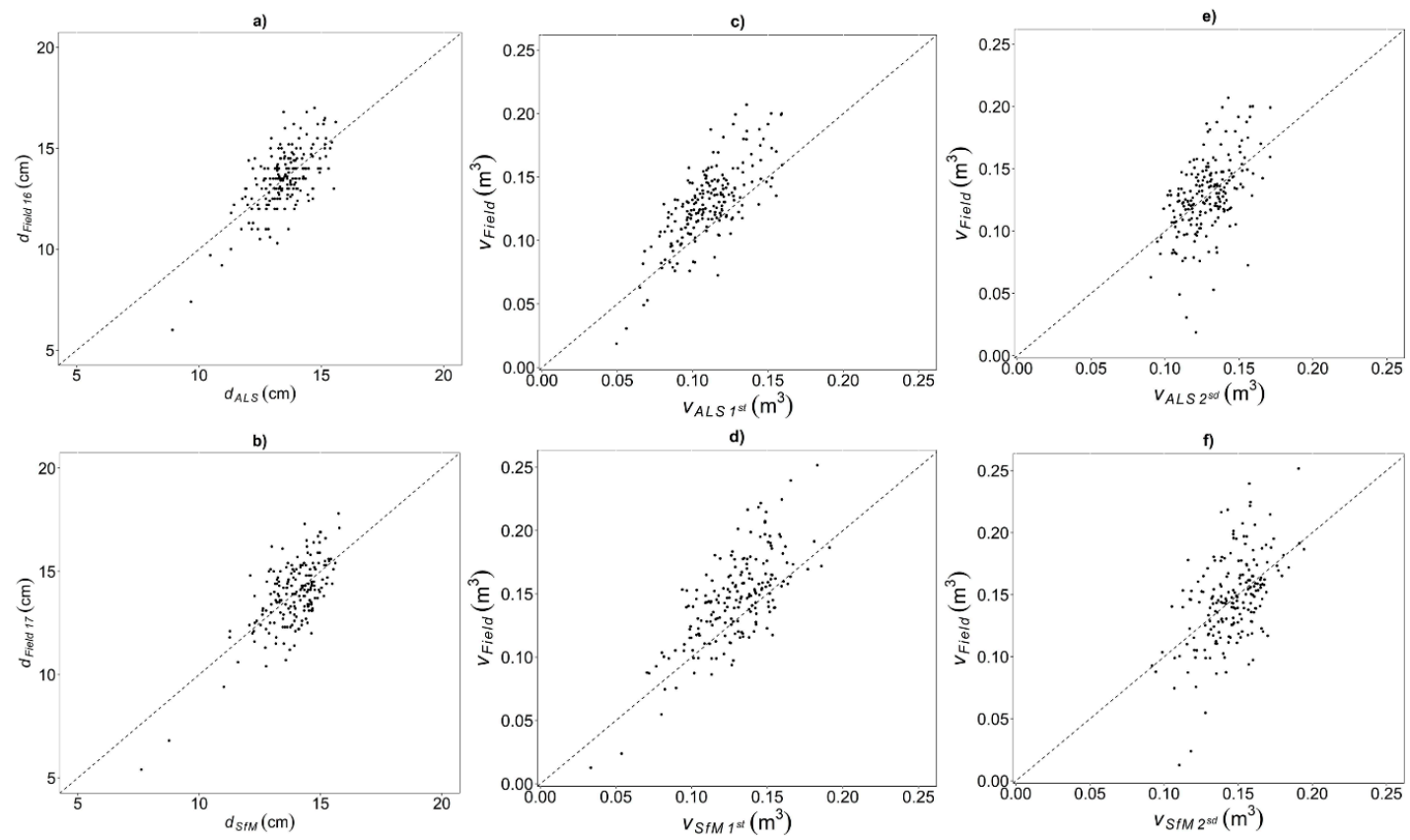

Figure 5. Scatter plots of ALS and SfM-derived variables against field-derived variables: (a) field-measured tree diameter $(d)$ against ALS-estimated tree diameter $\left(d_{A L S}\right)$; (b) field-measured tree diameter $(d)$ against SfM-estimated tree diameter $\left(d_{S f M}\right)$; (c) field-estimated volume $\left(v_{f i e l d}\right)$ against ALS-estimated volume $\left(v_{A L S}\right)$ using the first approach; $(\mathbf{d})$ field-estimated volume $\left(v_{\text {field }}\right)$ against SfM-estimated volume $\left(v_{S f M}\right)$ using the first approach; (e) field-estimated volume $\left(v_{\text {field }}\right)$ against ALS-estimated volume $\left(v_{A L S}\right)$ using the second approach; (f) field-estimated volume $\left(v_{\text {field }}\right)$ against SfM -estimated volume $\left(v_{S f M}\right)$ using the second approach. 
In the case of $v_{A L S}$ modelling, the second approach yielded an Mef value of 0.56 . The mean rRMSE of $v$ estimation was $20.31 \%\left(0.030 \mathrm{~m}^{3}\right)$ when calculated on the basis of the SfM cloud, and $19.97 \%\left(0.026 \mathrm{~m}^{3}\right)$ when based on the ALS cloud. There were no appreciable biases from the models throughout the observed volume range using both approaches (Figure $5 \mathrm{c}-\mathrm{f}$ ). However, the tendency of ALS and SfM to underestimate $h$ may be the main reason for the slight underestimation of $v$ in the first approach (Figure $5 c, d)$. In the case of the second approach, a slightly positive bias $(0.0004$ and $0.0016 \mathrm{~m}^{3}$ ) indicated slight overestimation when volume was modeled directly form ALS- and SfM-variables (Figure 5e,f).

The $t$-test (Table 3) showed that there were no evidence of significant differences between observed and estimated values of diameter ( $p$-values of 0.98 for both approaches in the subsample of 192 trees for SfM and 199 for ALS, respectively) and volume using the second approach ( $p$-values of 0.99 for ALS and 0.98 for SfM, Figure 6b). However, there were significant differences using the 1st approach between the observed values and estimated value at the tree level (Table 3, Figure 6b). It is important to note that the mean values of field data for diameter and volume computed for ALS and SfM in the subsample were similar that the values considering the 6 field plots for the total of 323 reference trees, except for the mean volume values for volume in 2017 (Table 3).

Table 3. Field, ALS and SfM diameter and volume estimations from both approaches with their minimum (Min.), mean (Mean), maximum (Max.) and standard deviation (SD) values and the results for the $t$-test in the subsample of 192 trees for SfM and 199 for ALS, respectively. Field 16 and Field 17 are the field data acquisition years for ALS (Dec 2016) and SfM (Sep 2017), respectively.

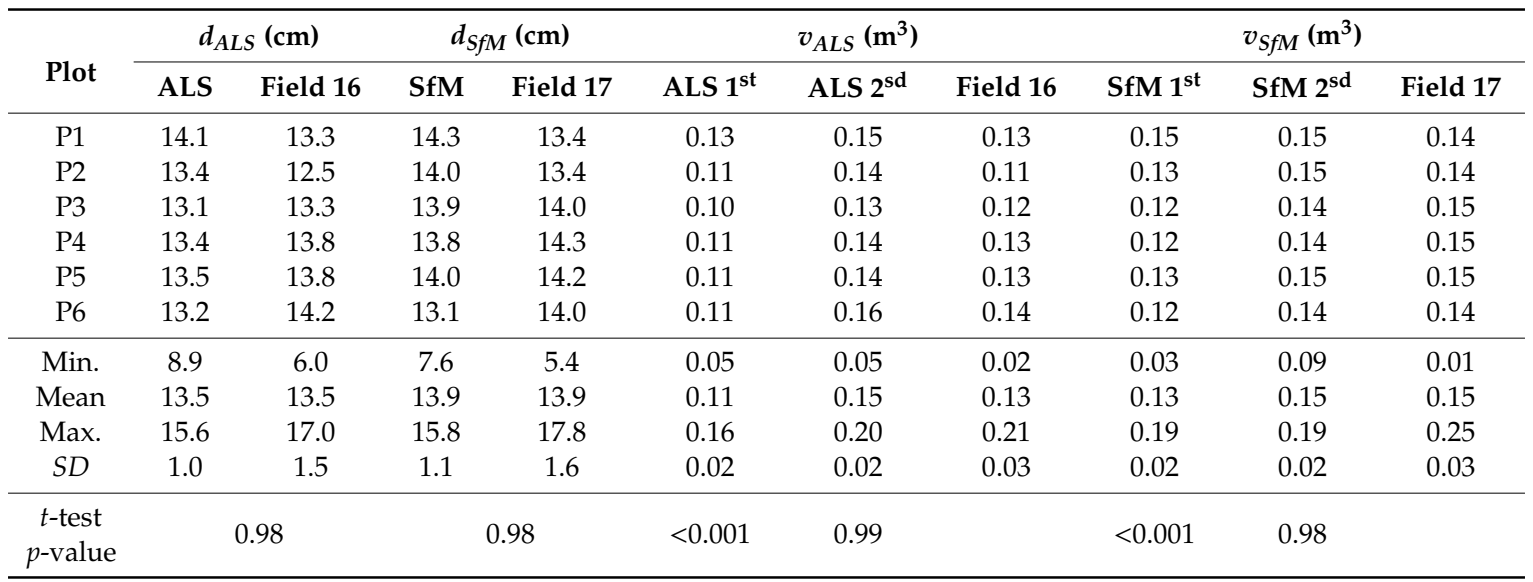


(a)

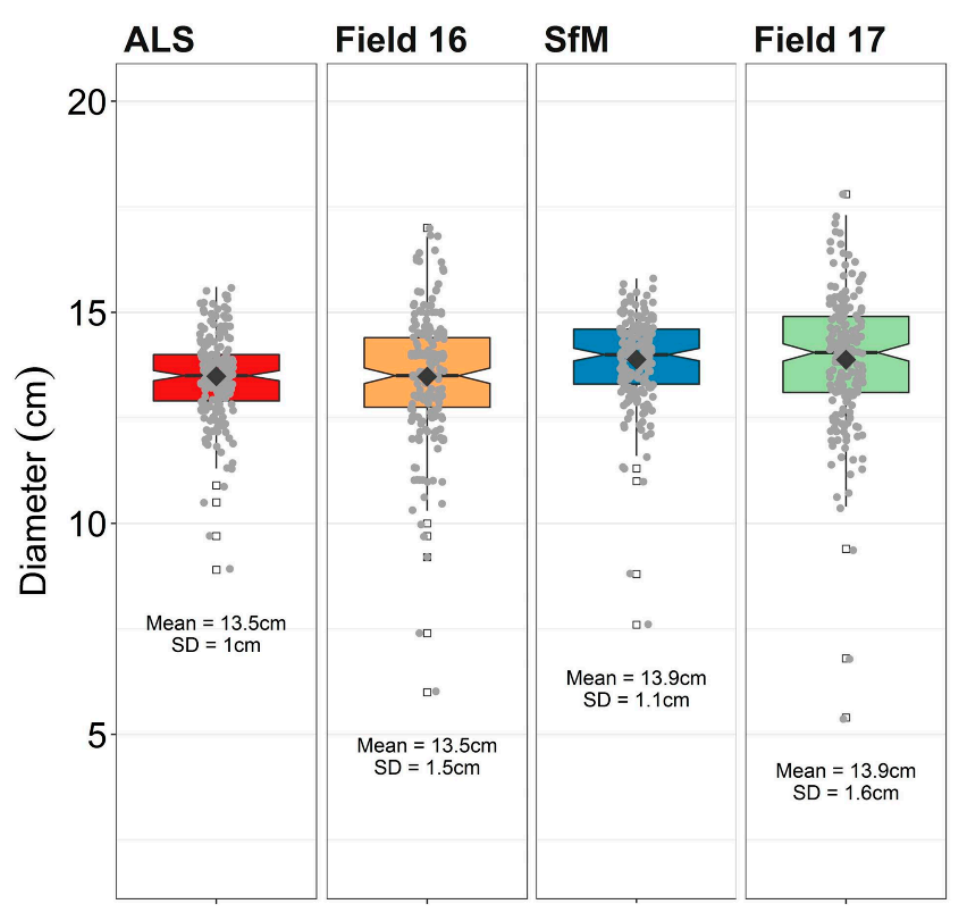

(b)

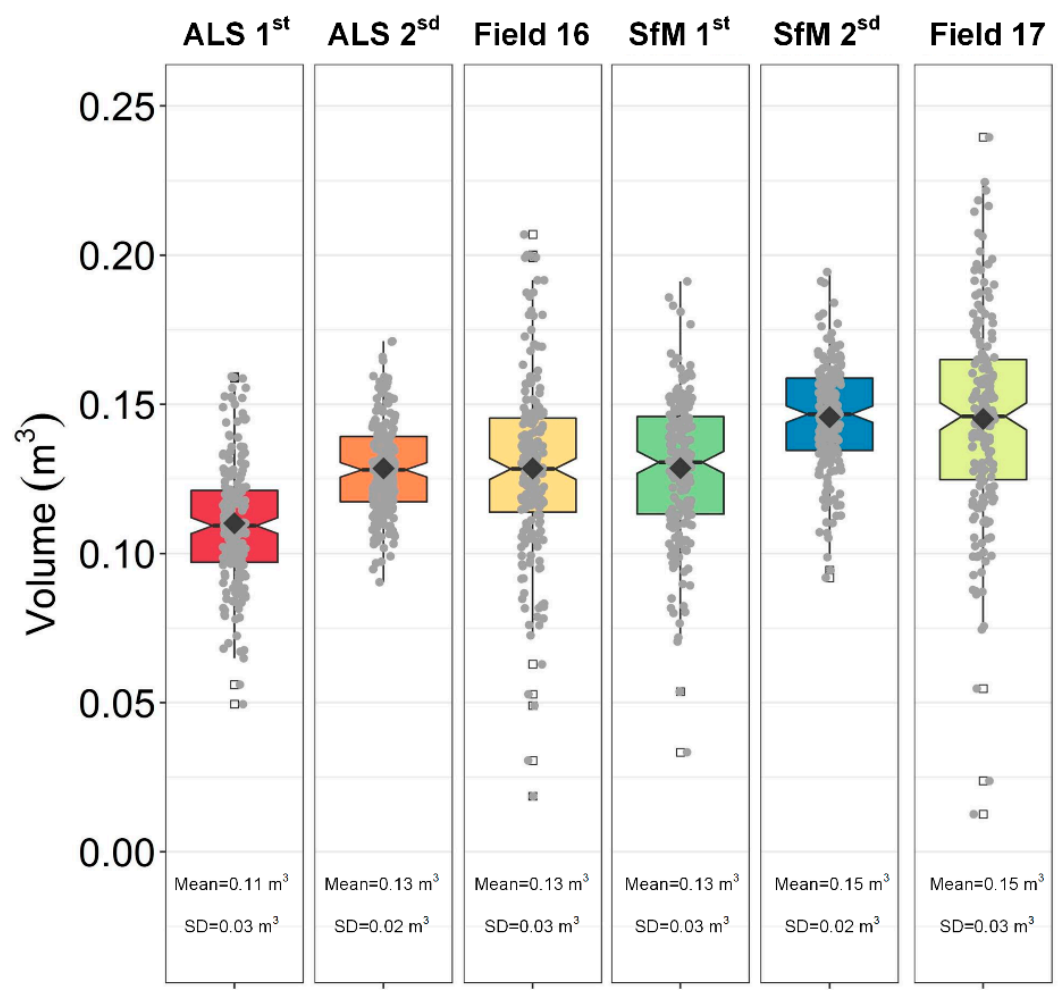

Figure 6. Box plot of field-measured and remotely sensed estimated values of diameter (a) and volume using the 1st approach and 2nd approach $(\mathbf{b})$. The lower and upper areas of the boxes represent the 5th and 75th percentiles and the horizontal band represents the median. The upper and lower whiskers extend from to the highest and lowest value respectively within the 1.5 times the interquartile range. 


\section{Discussion}

Both $v_{S f M}$ and $v_{A L S}$ were accurately estimated from UAV photograph and ALS-based 3-D point clouds using SfM- and ALS-variables extracted automatically from their respective CHMs. Although ALS-based methods and UAV-based DAP methods tend to underestimate tree height $[73,74,77]$, relative to field measurements (hypsometers), no appreciable biases in the observed diameter and volume range estimations occurred with either technologies in the 2nd approach.

Variables derived from the automated processing of ALS and UAV-based DAP with ITC delineation $\left(h_{S f M}, h_{A L S}, c a_{S f M}\right.$, and $\left.c a_{A L S}\right)$ were found to be significant explanatory variables for predicting $d$ and $v$ in both approaches; however, the Mef and RMSE values for diameter models indicate poorer fits than reported in some recent studies in P. pinea plantations [57] (Mef $=0.79, \mathrm{rRMSE}=4.99 \%, \mathrm{n}=50$ trees) and Japanese Cypress (Chamaecyparis obtusa) [84] $\left(R^{2}=0.79, \mathrm{n}=51\right.$ individual trees where $d$ ranged from 11 to $58 \mathrm{~cm}$ ) using UAV-based DAP point clouds.

In the case of ALS-based diameter models, our results were similar in terms of $R^{2}$ to those reported by Chisholm et al. [85], who extracted forest below-canopy information using UAV-based LiDAR and developed post-processing software to detect trees and to estimate their diameters $\left(R^{2}=0.45\right.$, rRMSE $=$ 25.1\%). Finally, the results were also similar in terms of rRMSE to those reported by Cosenza et al. [86] in a eucalyptus plantation in Brazil (rRMSE $=9 \%$ ), for an exponential equation with $h$ as explanatory variable. Cosenza et al. [86] also observed a slight tendency to overestimate the initial diameter values (bias $=0.12 \mathrm{~cm}$ ).

Studies conducted in Picea abies (L.) H. Karst. and Pinus sylvestris L. stands in Sweden and in Pinus taeda L. stands in the SE United States found that ALS-derived $h$ and crown diameter $(c d)$ explained up to $87 \%$ and $91 \%$ of the variance associated with the estimation of $d$, with RMSE of 3.8 and $4.9 \mathrm{~cm}$, respectively [87,88]. Zhao et al. [89] reported an $R^{2}$ value of 0.87 and a RMSE value of $5.2 \mathrm{~cm}$ for ALS-derived tree dimension variables including $h, c d$ and crown base height in P. taeda stands. In this study, the diameter equation based on ALS-derived variables performed well, although the values of Mef were slightly lower than some of those reported for other species $[87,88]$.

Regarding volume modelling, the performance of the $v_{A L S}$ and $v_{S f M}$ estimates for predicting tree volume directly from ALS- and SfM-derived variables (the second approach, $R^{2}=0.46, R^{2}=0.43$; RMSE $=0.026 \mathrm{~m}^{3}$, RMSE $=0.030 \mathrm{~m}^{3}$; respectively) was lower than that obtained in different conifer species $\left(R^{2}=0.88\right)$ [88], as well as in P. taeda $\left(R^{2}=0.80\right)$ [89] and P. pinea (Mef $\left.=0.84-0.85\right)$ [57]. The mean differences between the deviations of field volume and the ALS- or SfM-derived volume were statistically significant using the 1st approach. The tendency of ALS and UAV-based DAP technologies to underestimate $h$ may be the main reason for the underestimation of $v$ with 1st approach. It should be also borne in mind that the ALS and UAV-based DAP, as a tree height estimation technique, tends to underestimate tree height (e.g., DAP [39,90,91], UAV-based DAP [47,74,76,92] and ALS [73,77,93-95] point cloud data). However, our volume modelling results suggest that this bias may not influence in volume estimations using the 2nd approach, leaving open the question as to when and where specific models should be developed for correcting the bias at tree level depending on particular species or forest structure [77]. The results of this study are consistent with the approaches used by other authors $[57,73]$, in which the use of linear regression improved the accuracy of tree height estimations from DAP-ALS data in terms of RMSE and bias, instead of using tree height extracted directly from the CHM to calculate the RMSEs and bias [74], as also occurred with modelling volume in the present study.

There are three possible reasons for the differences in performance for diameter models using SfM- and ALS-variables relative to other species: (i) First, broadleaved trees trees in particular are more challenging for both local maxima detection and delineation compared to conifer trees. (ii) Second, crown delineation remains difficult because the crowns of neighboring trees often overlap due to the high density of trees per unit area. (iii) Third, the low density of leaves in the crowns and the small size of the crowns of mature trees prevent a considerable number of laser pulses from hitting the crown (thus hampering crown delineation). As expected, the ALS cloud contributed to yielding 
slightly better results for diameter and volume estimation, but we did not observe differences in terms of volume estimations. As with previous studies using DAP, ITC delineation is more affected than ALS crown delineation as UAV-based DAP has several limitations: (i) ALS is insensitive to shadows made by clouds [15], (ii) the images are strongly influenced by atmospheric conditions (e.g., wind swaying can cause problems building point clouds), solar illumination and view angles (sun, surface and sensor geometry), occlusions caused by shadows are particular problematic for generation of image-based point clouds in dense forest canopies [45,96-98]. In addition, seasonality (timing) influences underestimation of tree heights but can improve detection accuracy [99]. The allometric relationship between volume and ALS or SfM crown-derived variables could be also refined through improvements in UAV imagery acquisition and processing.

Finally, a more comprehensive examination of the effects of varying the conditions of UAV-based DAP acquisition and their implications for estimating forest inventory variables in different types of forest should be carried out using these techniques [100-102]. Many facets have not been explored with current state-of-the-art techniques. Several effects related to flight configuration (i.e., flight speed, wind effect, illumination effect), post-processing pipelines (i.e., comparing different SfM algorithms), field data collection (i.e., number of field plots) and environmental variables (i.e., effect of aspect or slope when using different DEM approaches or the DEM-independent approach) must be analyzed. Future research must also explore how the type of platform (fixed-wing versus multirotor), sensors or the type of forest (e.g., temperate, deciduous, evergreen needleleaf, and tropical forest) influence the ability of UAV-based DAP methods to accurately characterize biometric tree variables at the tree level.

\section{Conclusions}

The study findings showed that UAV-based DAP methods are useful and comparable to ALS for forest inventory and sustainable forest management in planted forests, by providing accurate estimations of forest structural attributes at the tree level. The results suggested that object-based image analysis (OBIA) provides more accurate predictive models for individual volumes of Eucalyptus trees based on ALS-derived and SfM-derived variables from the 3D point clouds than those obtained using indirect approaches to estimate diameter.

Author Contributions: Conceptualization, J.G.-H., D.N.C., A.C. and C.A.S.; Methodology, D.N.C., J.G.-H., B.B., and P.S.; Data Analysis, J.G.-H., D.N.C., and B.B.; Investigation, J.G.-H., D.N.C., B.B., E.G.-F. and R.A.D.-V.; Resources, M.S., and P.S.; Writing-Original Draft, J.G.-H., D.N.C., B.B., A.C., C.A.S. Preparation, J.G.-H., D.N.C., B.B., A.C., C.A.S., E.G.-F., and R.A.D.-V.; Writing-Review and Editing, J.G.-H., D.N.C., B.B., A.C., C.A.S., P.S., E.G.-F. and R.A.D.-V.; Funding acquisition, M.S.; Project Administration, M.S.; Supervision, E.G.-F. and R.A.D.-V.

Funding: We thank the Portuguese Science Foundation (grant number PD/BD/128489/2017)) for funding the research activities of Diogo Cosenza. This research was supported by RPJ17014 internal project-from Navigator company and BioEcosys 'Forest ecosystem management decision-making methods an integrated bioeconomic approach to sustainability', reference LISBOA-01-0145-FEDER-030391 - PTDC/ASP-SII/30391/2017, funded by the Fundação para a Ciência e a Tecnologia (FCT, Portugal).

Acknowledgments: We gratefully acknowledge RAIZ and the Navigator Company for supplying the inventory databases and support the airborne surveys and TLS field work. We also acknowledge support from Terradrone Co. during the airborne survey. The research was carried out in the Centro de Estudos Florestais: a research unit funded by Fundação para a Ciência e a Tecnologia I.P. (FCT), Portugal within UID/AGR/00239/2019.

Conflicts of Interest: The authors declare no conflict of interest.

\section{References}

1. Burkhart, H.E.; Tomé, M. Modeling Forest Trees and Stands; Springer Science \& Business Media: Dordrecht, The Netherlands, 2012.

2. Bauwens, S.; Bartholomeus, H.; Calders, K.; Lejeune, P. Forest Inventory with Terrestrial LiDAR: A Comparison of Static and Hand-Held Mobile Laser Scanning. Forests 2016, 7, 127. [CrossRef]

3. Williams, M.S.; Bechtold, W.A.; LaBau, V.J. Five Instruments for Measuring Tree Height: An Evaluation. South. J. Appl. For. 1994, 18, 76-82. [CrossRef] 
4. Thenkabail, P.S.; Durrieu, S.; Véga, C.; Bouvier, M.; Gosselin, F.; Renaud, J.-P.; Saint-André, L. Optical Remote Sensing of Tree and Stand Heights. In Land Resources Monitoring, Modeling, and Mapping with Remote Sensing; CRC Press: Boca Raton, FL, USA, 2015; pp. 449-485.

5. Díaz-Varela, R.A.; de la Rosa, R.; León, L.; Zarco-Tejada, P.J. High-Resolution Airborne UAV Imagery to Assess Olive Tree Crown Parameters Using 3D Photo Reconstruction: Application in Breeding Trials. Remote Sens. 2015, 7, 4213-4232. [CrossRef]

6. Panagiotidis, D.; Abdollahnejad, A.; Surový, P.; Chiteculo, V. Determining Tree Height and Crown Diameter from High-Resolution UAV Imagery. Int. J. Remote Sens. 2016, 1-19. [CrossRef]

7. White, J.C.; Coops, N.C.; Wulder, M.A.; Vastaranta, M.; Hilker, T.; Tompalski, P. Remote Sensing Technologies for Enhancing Forest Inventories: A Review. Can. J. Remote Sens. 2016, 1-23. [CrossRef]

8. Giannetti, F.; Puletti, N.; Quatrini, V.; Travaglini, D.; Bottalico, F.; Corona, P.; Chirici, G. Integrating Terrestrial and Airborne Laser Scanning for the Assessment of Single-Tree Attributes in Mediterranean Forest Stands. Eur. J. Remote Sens. 2018, 51, 795-807. [CrossRef]

9. Liang, X.; Kankare, V.; Hyyppä, J.; Wang, Y.; Kukko, A.; Haggrén, H.; Yu, X.; Kaartinen, H.; Jaakkola, A.; Guan, F. Terrestrial Laser Scanning in Forest Inventories. ISPRS J. Photogramm. Remote Sens. 2016, 115, 63-77. [CrossRef]

10. Abegg, M.; Kükenbrink, D.; Zell, J.; Schaepman, M.E.; Morsdorf, F. Terrestrial Laser Scanning for Forest Inventories-Tree Diameter Distribution and Scanner Location Impact on Occlusion. Forests 2017, 8, 184. [CrossRef]

11. Liu, G.; Wang, J.; Dong, P.; Chen, Y.; Liu, Z. Estimating Individual Tree Height and Diameter at Breast Height (DBH) from Terrestrial Laser Scanning (TLS) Data at Plot Level. Forests 2018, 9, 398. [CrossRef]

12. Baltsavias, E.P. A Comparison between Photogrammetry and Laser Scanning. ISPRS J. Photogramm. Remote Sens. 1999, 54, 83-94. [CrossRef]

13. Næsset, E. Determination of Mean Tree Height of Forest Stands by Digital Photogrammetry. Scand. J. For. Res. 2002, 17, 446-459. [CrossRef]

14. Næsset, E. Predicting Forest Stand Characteristics with Airborne Scanning Laser Using a Practical Two-Stage Procedure and Field Data. Remote Sens. Environ. 2002, 80, 88-99. [CrossRef]

15. White, J.; Wulder, M.; Vastaranta, M.; Coops, N.; Pitt, D.; Woods, M. The Utility of Image-Based Point Clouds for Forest Inventory: A Comparison with Airborne Laser Scanning. Forests 2013, 4, 518-536. [CrossRef]

16. Fritz, A.; Kattenborn, T.; Koch, B. UAV-Based Photogrammetric Point Clouds-Tree Stem Mapping in Open Stands in Comparison to Terrestrial Laser Scanner Point Clouds. Int. Arch. Photogramm. Remote Sens. Spat. Inf. Sci. 2013, 40, 141-146. [CrossRef]

17. Gobakken, T.; Bollandsås, O.M.; Næsset, E. Comparing Biophysical Forest Characteristics Estimated from Photogrammetric Matching of Aerial Images and Airborne Laser Scanning Data. Scand. J. For. Res. 2015, 30, 73-86. [CrossRef]

18. Maltamo, M.; Næsset, E.; Vauhkonen, J. Forestry Applications of Airborne Laser Scanning. Concepts Case Stud. Manag. Ecosys 2014, 27, 2014.

19. Naesset, E. Estimating Timber Volume of Forest Stands Using Airborne Laser Scanner Data. Remote Sens. Environ. 1997, 61, 246-253. [CrossRef]

20. Hyyppä, J.; Hyyppä, H.; Leckie, D.; Gougeon, F.; Yu, X.; Maltamo, M. Review of Methods of Small-Footprint Airborne Laser Scanning for Extracting Forest Inventory Data in Boreal Forests. Int. J. Remote Sens. 2008, 29, 1339-1366. [CrossRef]

21. Van Leeuwen, M.; Nieuwenhuis, M. Retrieval of Forest Structural Parameters Using LiDAR Remote Sensing. Eur. J. For. Res. 2010, 129, 749-770. [CrossRef]

22. Puliti, S.; Gobakken, T.; Ørka, H.O.; Næsset, E. Assessing 3D Point Clouds from Aerial Photographs for Species-Specific Forest Inventories. Scand. J. For. Res. 2017, 32, 68-79. [CrossRef]

23. Tuominen, S.; Balazs, A.; Saari, H.; Pölönen, I.; Sarkeala, J.; Viitala, R. Unmanned Aerial System Imagery and Photogrammetric Canopy Height Data in Area-Based Estimation of Forest Variables. Silva Fenn. 2015, 49. [CrossRef]

24. Bohlin, J.; Wallerman, J.; Fransson, J.E. Forest Variable Estimation Using Photogrammetric Matching of Digital Aerial Images in Combination with a High-Resolution DEM. Scand. J. For. Res. 2012, 27, 692-699. [CrossRef]

25. Nurminen, K.; Karjalainen, M.; Yu, X.; Hyyppä, J.; Honkavaara, E. Performance of Dense Digital Surface Models Based on Image Matching in the Estimation of Plot-Level Forest Variables. ISPRS J. Photogramm. Remote Sens. 2013, 83, 104-115. [CrossRef] 
26. St-Onge, B.; Vega, C.; Fournier, R.A.; Hu, Y. Mapping Canopy Height Using a Combination of Digital Stereo-photogrammetry and Lidar. Int. J. Remote Sens. 2008, 29, 3343-3364. [CrossRef]

27. Zarco-Tejada, P.J.; Diaz-Varela, R.; Angileri, V.; Loudjani, P. Tree Height Quantification Using Very High Resolution Imagery Acquired from an Unmanned Aerial Vehicle (UAV) and Automatic 3D Photo-Reconstruction Methods. Eur. J. Agron. 2014, 55, 89-99. [CrossRef]

28. Goodbody, T.R.; Coops, N.C.; White, J.C. Digital Aerial Photogrammetry for Updating Area-Based Forest Inventories: A Review of Opportunities, Challenges, and Future Directions. Curr. For. Rep. 2019, 5, 55-75. [CrossRef]

29. Iglhaut, J.; Cabo, C.; Puliti, S.; Piermattei, L.; O'Connor, J.; Rosette, J. Structure from Motion Photogrammetry in Forestry: A Review. Curr. For. Rep. 2019, 1-14. [CrossRef]

30. White, J.C.; Stepper, C.; Tompalski, P.; Coops, N.C.; Wulder, M.A. Comparing ALS and Image-Based Point Cloud Metrics and Modelled Forest Inventory Attributes in a Complex Coastal Forest Environment. Forests 2015, 6, 3704-3732. [CrossRef]

31. Baltsavias, E.; Gruen, A.; Eisenbeiss, H.; Zhang, L.; Waser, L.T. High-quality Image Matching and Automated Generation of 3D Tree Models. Int. J. Remote Sens. 2008, 29, 1243-1259. [CrossRef]

32. Véga, C.; St-Onge, B. Height Growth Reconstruction of a Boreal Forest Canopy over a Period of 58 Years Using a Combination of Photogrammetric and Lidar Models. Remote Sens. Environ. 2008, 112, 1784-1794. [CrossRef]

33. Waser, L.T.; Baltsavias, E.; Ecker, K.; Eisenbeiss, H.; Feldmeyer-Christe, E.; Ginzler, C.; Küchler, M.; Zhang, L. Assessing Changes of Forest Area and Shrub Encroachment in a Mire Ecosystem Using Digital Surface Models and CIR Aerial Images. Remote Sens. Environ. 2008, 112, 1956-1968. [CrossRef]

34. Vastaranta, M.; Wulder, M.A.; White, J.C.; Pekkarinen, A.; Tuominen, S.; Ginzler, C.; Kankare, V.; Holopainen, M.; Hyyppä, J.; Hyyppä, H. Airborne Laser Scanning and Digital Stereo Imagery Measures of Forest Structure: Comparative Results and Implications to Forest Mapping and Inventory Update. Can. J. Remote Sens. 2013, 39, 382-395. [CrossRef]

35. Pitt, D.G.; Woods, M.; Penner, M. A Comparison of Point Clouds Derived from Stereo Imagery and Airborne Laser Scanning for the Area-Based Estimation of Forest Inventory Attributes in Boreal Ontario. Can. J. Remote Sens. 2014, 40, 214-232. [CrossRef]

36. Rahlf, J.; Breidenbach, J.; Solberg, S.; Næsset, E.; Astrup, R. Comparison of Four Types of 3D Data for Timber Volume Estimation. Remote Sens. Environ. 2014, 155, 325-333. [CrossRef]

37. Ota, T.; Ogawa, M.; Shimizu, K.; Kajisa, T.; Mizoue, N.; Yoshida, S.; Takao, G.; Hirata, Y.; Furuya, N.; Sano, T. Aboveground Biomass Estimation Using Structure from Motion Approach with Aerial Photographs in a Seasonal Tropical Forest. Forests 2015, 6, 3882-3898. [CrossRef]

38. Holopainen, M.; Vastaranta, M.; Karjalainen, M.; Karila, K.; Kaasalainen, S.; Honkavaara, E.; Hyyppä, J. Forest Inventory Attribute Estimation Using Airborne Laser Scanning, Aerial Stereo Imagery, Radargrammetry and Interferometry-Finnish Experiences of the 3D Techniques. ISPRS Ann. Photogramm. Remote Sens. Spat. Inf. Sci. 2015, 2, 63. [CrossRef]

39. Tanhuanpää, T.; Saarinen, N.; Kankare, V.; Nurminen, K.; Vastaranta, M.; Honkavaara, E.; Karjalainen, M.; Yu, X.; Holopainen, M.; Hyyppä, J. Evaluating the Performance of High-Altitude Aerial Image-Based Digital Surface Models in Detecting Individual Tree Crowns in Mature Boreal Forests. Forests 2016, 7, 143. [CrossRef]

40. Wallace, L.; Lucieer, A.; Watson, C.; Turner, C. Assessing the Feasibility of UAV-Based LiDAR for High Resolution Forest Change Detection. Proc. ISPRS—Int. Arch. Photogramm. Remote Sens. Spat. Inf. Sci. 2012, 39, B7. [CrossRef]

41. Lisein, J.; Pierrot-Deseilligny, M.; Bonnet, S.; Lejeune, P. A Photogrammetric Workflow for the Creation of a Forest Canopy Height Model from Small Unmanned Aerial System Imagery. Forests 2013, 4, 922-944. [CrossRef]

42. Wallace, L.; Lucieer, A.; Malenovský, Z.; Turner, D.; Vopěnka, P. Assessment of Forest Structure Using Two UAV Techniques: A Comparison of Airborne Laser Scanning and Structure from Motion (SfM) Point Clouds. Forests 2016, 7, 62. [CrossRef]

43. Jaakkola, A.; Hyyppä, J.; Yu, X.; Kukko, A.; Kaartinen, H.; Liang, X.; Hyyppä, H.; Wang, Y. Autonomous Collection of Forest Field Reference-The Outlook and a First Step with UAV Laser Scanning. Remote Sens. 2017, 9, 785. [CrossRef]

44. Dandois, J.P.; Ellis, E.C. Remote Sensing of Vegetation Structure Using Computer Vision. Remote Sens. 2010, 2, 1157-1176. [CrossRef]

45. Dandois, J.P.; Olano, M.; Ellis, E.C. Optimal Altitude, Overlap, and Weather Conditions for Computer Vision UAV Estimates of Forest Structure. Remote Sens. 2015, 7, 13895-13920. [CrossRef] 
46. Dandois, J.P.; Ellis, E.C. High Spatial Resolution Three-Dimensional Mapping of Vegetation Spectral Dynamics Using Computer Vision. Remote Sens. Environ. 2013, 136, 259-276. [CrossRef]

47. Zahawi, R.A.; Dandois, J.P.; Holl, K.D.; Nadwodny, D.; Reid, J.L.; Ellis, E.C. Using Lightweight Unmanned Aerial Vehicles to Monitor Tropical Forest Recovery. Biol. Conserv. 2015, 186, 287-295. [CrossRef]

48. Guerra-Hérnandez, J.; González-Ferreiro, E.; Sarmento, A.; Silva, J.; Nunes, A.; Correia, A.C.; Fontes, L.; Tomé, M.; Díaz-Varela, R. Short Communication. Using High Resolution UAV Imagery to Estimate Tree Variables in Pinus Pinea Plantation in Portugal. For. Syst. 2016, 25, 9. [CrossRef]

49. Mohan, M.; Silva, C.A.; Klauberg, C.; Jat, P.; Catts, G.; Cardil, A.; Hudak, A.T.; Dia, M. Individual Tree Detection from Unmanned Aerial Vehicle (UAV) Derived Canopy Height Model in an Open Canopy Mixed Conifer Forest. Forests 2017, 8, 340. [CrossRef]

50. Thiel, C.; Schmullius, C. Comparison of UAV Photograph-Based and Airborne Lidar-Based Point Clouds over Forest from a Forestry Application Perspective. Int. J. Remote Sens. 2017, 38, 2411-2426. [CrossRef]

51. Cardil, A.; Vepakomma, U.; Brotons, L. Assessing Pine Processionary Moth Defoliation Using Unmanned Aerial Systems. Forests 2017, 8, 402. [CrossRef]

52. Navarro, J.; Algeet, N.; Fernández-Landa, A.; Esteban, J.; Rodríguez-Noriega, P.; Guillén-Climent, M. Integration of UAV, Sentinel-1, and Sentinel-2 Data for Mangrove Plantation Aboveground Biomass Monitoring in Senegal. Remote Sens. 2019, 11, 77. [CrossRef]

53. Puliti, S.; Ørka, H.O.; Gobakken, T.; Næsset, E. Inventory of Small Forest Areas Using an Unmanned Aerial System. Remote Sens. 2015, 7, 9632-9654. [CrossRef]

54. Torresan, C.; Berton, A.; Carotenuto, F.; Di Gennaro, S.F.; Gioli, B.; Matese, A.; Miglietta, F.; Vagnoli, C.; Zaldei, A.; Wallace, L. Forestry Applications of UAVs in Europe: A Review. Int. J. Remote Sens. 2017, 38, 2427-2447. [CrossRef]

55. Whitehead, K.; Hugenholtz, C.H. Remote Sensing of the Environment with Small Unmanned Aircraft Systems (UASs), Part 1: A Review of Progress and Challenges 1. J. Unmanned Veh. Syst. 2014, 2, 69-85. [CrossRef]

56. Tang, L.; Shao, G. Drone Remote Sensing for Forestry Research and Practices. J. For. Res. 2015, 1-7. [CrossRef]

57. Guerra-Hernández, J.; González-Ferreiro, E.; Monleón, V.; Faias, S.; Tomé, M.; Díaz-Varela, R. Use of Multi-Temporal UAV-Derived Imagery for Estimating Individual Tree Growth in Pinus Pinea Stands. Forests 2017, 8, 300. [CrossRef]

58. Pádua, L.; Hruška, J.; Bessa, J.; Adão, T.; Martins, L.M.; Gonçalves, J.A.; Peres, E.; Sousa, A.M.; Castro, J.P.; Sousa, J.J. Multi-Temporal Analysis of Forestry and Coastal Environments Using UASs. Remote Sens. 2017, 10, 24. [CrossRef]

59. Hall, S.A.; Burke, I.C.; Box, D.O.; Kaufmann, M.R.; Stoker, J.M. Estimating Stand Structure Using Discrete-Return Lidar: An Example from Low Density, Fire Prone Ponderosa Pine Forests. For. Ecol. Manag. 2005, 208, 189-209. [CrossRef]

60. Järnstedt, J.; Pekkarinen, A.; Tuominen, S.; Ginzler, C.; Holopainen, M.; Viitala, R. Forest Variable Estimation Using a High-Resolution Digital Surface Model. ISPRS J. Photogramm. Remote Sens. 2012, 74, 78-84. [CrossRef]

61. González-Ferreiro, E.; Diéguez-Aranda, U.; Miranda, D. Estimation of Stand Variables in Pinus Radiata D. Don Plantations Using Different LiDAR Pulse Densities. Forestry 2012, 85, 281-292. [CrossRef]

62. González-Ferreiro, E.; Diéguez-Aranda, U.; Crecente-Campo, F.; Barreiro-Fernández, L.; Miranda, D.; Castedo-Dorado, F. Modelling Canopy Fuel Variables for Pinus Radiata D. Don in NW Spain with Low-Density LiDAR Data. Int. J. Wildland Fire 2014, 23, 350-362. [CrossRef]

63. Montaghi, A.; Corona, P.; Dalponte, M.; Gianelle, D.; Chirici, G.; Olsson, H. Airborne Laser Scanning of Forest Resources: An Overview of Research in Italy as a Commentary Case Study. Int. J. Appl. Earth Obs. Geoinformation 2013, 23, 288-300. [CrossRef]

64. Corona, P.; Cartisano, R.; Salvati, R.; Chirici, G.; Floris, A.; Di Martino, P.; Marchetti, M.; Scrinzi, G.; Clementel, F.; Torresan, C. Airborne Laser Scanning to Support Forest Resource Management under Alpine, Temperate and Mediterranean Environments in Italy. Eur. J. Remote Sens. 2012, 45, 27-37.

65. González-Olabarria, J.-R.; Rodríguez, F.; Fernández-Landa, A.; Mola-Yudego, B. Mapping Fire Risk in the Model Forest of Urbión (Spain) Based on Airborne LiDAR Measurements. For. Ecol. Manag. 2012, 282, 149-156. [CrossRef]

66. Guerra-Hernández, J.; Görgens, E.B.; García-Gutiérrez, J.; Rodriguez, L.C.E.; Tomé, M.; González-Ferreiro, E. Comparison of ALS Based Models for Estimating Aboveground Biomass in Three Types of Mediterranean Forest. Eur. J. Remote Sens. 2016, 49, 185-204. [CrossRef] 
67. Montealegre, A.L.; Lamelas, M.T.; Tanase, M.A.; de la Riva, J. Estimación de La Severidad En Incendios Forestales a Partir de Datos LiDAR-PNOA y Valores de Composite Burn Index. Rev. Teledetec. 2017, 49, 1-16. [CrossRef]

68. Montealegre, A.L.; Lamelas, M.T.; de la Riva, J.; García-Martín, A.; Escribano, F. Use of Low Point Density ALS Data to Estimate Stand-Level Structural Variables in Mediterranean Aleppo Pine Forest. For. Int. J. For. Res. 2016, 89, 373-382. [CrossRef]

69. Domingo, D.; Alonso, R.; Lamelas, M.T.; Montealegre, A.L.; Rodríguez, F.; de la Riva, J. Temporal Transferability of Pine Forest Attributes Modeling Using Low-Density Airborne Laser Scanning Data. Remote Sens. 2019, 11, 261. [CrossRef]

70. Silva, C.A.; Klauberg, C.; Hudak, A.T.; Vierling, L.A.; Liesenberg, V.; Carvalho, S.P.E.; Rodriguez, L.C. A Principal Component Approach for Predicting the Stem Volume in Eucalyptus Plantations in Brazil Using Airborne LiDAR Data. For. Int. J. For. Res. 2016, 89, 422-433. [CrossRef]

71. Kachamba, D.J.; Ørka, H.O.; Gobakken, T.; Eid, T.; Mwase, W. Biomass Estimation Using 3D Data from Unmanned Aerial Vehicle Imagery in a Tropical Woodland. Remote Sens. 2016, 8, 968. [CrossRef]

72. St-Onge, B.; Audet, F.-A.; Bégin, J. Characterizing the Height Structure and Composition of a Boreal Forest Using an Individual Tree Crown Approach Applied to Photogrammetric Point Clouds. Forests 2015, 6, 3899-3922. [CrossRef]

73. Mielcarek, M.; Stereńczak, K.; Khosravipour, A. Testing and Evaluating Different LiDAR-Derived Canopy Height Model Generation Methods for Tree Height Estimation. Int. J. Appl. Earth Obs. Geoinformation 2018, 71, 132-143. [CrossRef]

74. Guerra-Hernández, J.; Cosenza, D.N.; Rodriguez, L.C.E.; Silva, M.; Tomé, M.; Díaz-Varela, R.A.; González-Ferreiro, E. Comparison of ALS-and UAV (SfM)-Derived High-Density Point Clouds for Individual Tree Detection in Eucalyptus Plantations. Int. J. Remote Sens. 2018, 39, 5211-5235.

75. Maltamo, M.; Eerikäinen, K.; Packalén, P.; Hyyppä, J. Estimation of Stem Volume Using Laser Scanning-Based Canopy Height Metrics. Forestry 2006, 79, 217-229. [CrossRef]

76. Hentz, Â.M.; Silva, C.A.; Dalla Corte, A.P.; Netto, S.P.; Strager, M.P.; Klauberg, C. Estimating Forest Uniformity in Eucalyptus Spp. and Pinus Taeda L. Stands Using Field Measurements and Structure from Motion Point Clouds Generated from Unmanned Aerial Vehicle (UAV) Data Collection. For. Syst. 2018, 27, 5. [CrossRef]

77. Roussel, J.-R.; Caspersen, J.; Béland, M.; Thomas, S.; Achim, A. Removing Bias from LiDAR-Based Estimates of Canopy Height: Accounting for the Effects of Pulse Density and Footprint Size. Remote Sens. Environ. 2017, 198, 1-16. [CrossRef]

78. Tomé, M.; Tomé, J.; Ribeiro, F.; Faias, S. Equações de Volume Total, Volume Percentual e de Perfil Do Tronco Para Eucalyptus Globulus Labill. Em Portugal. Silva Lusit. 2007, 15, 25-39.

79. McGaughey, R.J. FUSION/LDV: Software for LIDAR Data Analysis and Visualization; Version 3.60+; Pacific Northwest Research Station, United States Department of Agriculture Forest Service: Seattle, WA, USA, 2017.

80. Isenburg, M. LAStools_Efficient Tools for LiDAR Processing; Version 160921; Academic: Cambridge, MA, USA, 2016.

81. González-Ferreiro, E.; Diéguez-Aranda, U.; Barreiro-Fernández, L.; Buján, S.; Barbosa, M.; Suárez, J.C.; Bye, I.J.; Miranda, D. A Mixed Pixel-and Region-Based Approach for Using Airborne Laser Scanning Data for Individual Tree Crown Delineation in Pinus Radiata D. Don Plantations. Int. J. Remote Sens. 2013, 34, 7671-7690. [CrossRef]

82. Vanclay, J.K.; Skovsgaard, J.P. Evaluating Forest Growth Models. Ecol. Model. 1997, 98, 1-12. [CrossRef]

83. Shapiro, S.S.; Wilk, M.B.; Chen, H.J. A Comparative Study of Various Tests for Normality. J. Am. Stat. Assoc. 1968, 63, 1343-1372. [CrossRef]

84. Iizuka, K.; Yonehara, T.; Itoh, M.; Kosugi, Y. Estimating Tree Height and Diameter at Breast Height (DBH) from Digital Surface Models and Orthophotos Obtained with an Unmanned Aerial System for a Japanese Cypress (Chamaecyparis Obtusa) Forest. Remote Sens. 2017, 10, 13. [CrossRef]

85. Chisholm, R.A.; Cui, J.; Lum, S.K.; Chen, B.M. UAV LiDAR for Below-Canopy Forest Surveys. J. Unmanned Veh. Syst. 2013, 1, 61-68. [CrossRef]

86. Cosenza, D.N.; Soares, V.P.; Leite, H.G.; Gleriani, J.M.; do Amaral, C.H.; Gripp Júnior, J.; da Silva, A.A.L.; Soares, P.; Tomé, M. Airborne Laser Scanning Applied to Eucalyptus Stand Inventory at Individual Tree Level. Pesqui. Agropecuária Bras. 2018, 53, 1373-1382. [CrossRef] 
87. Persson, A.; Holmgren, J.; Söderman, U. Detecting and Measuring Individual Trees Using an Airborne Laser Scanner. Photogramm. Eng. Remote Sens. 2002, 68, 925-932.

88. Popescu, S.C. Estimating Biomass of Individual Pine Trees Using Airborne Lidar. Biomass Bioenergy 2007, 31, 646-655. [CrossRef]

89. Zhao, K.; Popescu, S.; Nelson, R. Lidar Remote Sensing of Forest Biomass: A Scale-Invariant Estimation Approach Using Airborne Lasers. Remote Sens. Environ. 2009, 113, 182-196. [CrossRef]

90. Korpela, I. Individual Tree Measurements by Means of Digital Aerial Photogrammetry; Finnish Society of Forest Science: Helsinki, Finland, 2004; Volume 3.

91. St-Onge, B.; Jumelet, J.; Cobello, M.; Véga, C. Measuring Individual Tree Height Using a Combination of Stereophotogrammetry and Lidar. Can. J. For. Res. 2004, 34, 2122-2130. [CrossRef]

92. Jensen, J.L.; Mathews, A.J. Assessment of Image-Based Point Cloud Products to Generate a Bare Earth Surface and Estimate Canopy Heights in a Woodland Ecosystem. Remote Sens. 2016, 8, 50. [CrossRef]

93. Hopkinson, C.; Chasmer, L.; Hall, R.J. The Uncertainty in Conifer Plantation Growth Prediction from Multi-Temporal Lidar Datasets. Remote Sens. Environ. 2008, 112, 1168-1180. [CrossRef]

94. Yu, X.; Hyyppä, J.; Kukko, A.; Maltamo, M.; Kaartinen, H. Change Detection Techniques for Canopy Height Growth Measurements Using Airborne Laser Scanner Data. Photogramm. Eng. Remote Sens. 2006, 72, 1339-1348. [CrossRef]

95. Gatziolis, D.; Fried, J.S.; Monleon, V.S. Challenges to Estimating Tree Height via LiDAR in Closed-Canopy Forests: A Parable from Western Oregon. For. Sci. 2010, 56, 139-155.

96. Milas, A.S.; Arend, K.; Mayer, C.; Simonson, M.A.; Mackey, S. Different Colours of Shadows: Classification of UAV Images. Int. J. Remote Sens. 2017, 38, 3084-3100. [CrossRef]

97. Laliberte, A.S.; Herrick, J.E.; Rango, A.; Winters, C. Acquisition, Orthorectification, and Object-Based Classification of Unmanned Aerial Vehicle (UAV) Imagery for Rangeland Monitoring. Photogramm. Eng. Remote Sens. 2010, 76, 661-672. [CrossRef]

98. Ke, Y.; Quackenbush, L.J. A Review of Methods for Automatic Individual Tree-Crown Detection and Delineation from Passive Remote Sensing. Int. J. Remote Sens. 2011, 32, 4725-4747. [CrossRef]

99. Nuijten, R.J.; Coops, N.C.; Goodbody, T.R.; Pelletier, G. Examining the Multi-Seasonal Consistency of Individual Tree Segmentation on Deciduous Stands Using Digital Aerial Photogrammetry (DAP) and Unmanned Aerial Systems (UAS). Remote Sens. 2019, 11, 739. [CrossRef]

100. Frey, J.; Kovach, K.; Stemmler, S.; Koch, B. UAV Photogrammetry of Forests as a Vulnerable Process. A Sensitivity Analysis for a Structure from Motion RGB-Image Pipeline. Remote Sens. 2018, 10, 912. [CrossRef]

101. Fraser, B.; Congalton, R. Issues in Unmanned Aerial Systems (UAS) Data Collection of Complex Forest Environments. Remote Sens. 2018, 10, 908. [CrossRef]

102. Ni, W.; Sun, G.; Pang, Y.; Zhang, Z.; Liu, J.; Yang, A.; Wang, Y.; Zhang, D. Mapping Three-Dimensional Structures of Forest Canopy Using UAV Stereo Imagery: Evaluating Impacts of Forward Overlaps and Image Resolutions With LiDAR Data as Reference. IEEE J. Sel. Top. Appl. Earth Obs. Remote Sens. 2018, 11, 3578-3589. [CrossRef]

(C) 2019 by the authors. Licensee MDPI, Basel, Switzerland. This article is an open access article distributed under the terms and conditions of the Creative Commons Attribution (CC BY) license (http://creativecommons.org/licenses/by/4.0/). 